\title{
Possible participation of mitochondria in lipid yolk formation in oocytes of paddlefish and sturgeon
}

\author{
Monika Żelazowska • Wincenty Kilarski
}

Published online: 28 January 2009

(C) Springer-Verlag 2009

Erratum to: Cell Tissue Res

DOI 10.1007/s00441-007-0459-6

Unfortunately, the e-mail address contained error. The correct e-mail address is given here.

The online version of the original article can be found at http://dx.doi. org/10.1007/s00441-007-0459-6.

M. Żelazowska $(\bowtie)$

Department of Systematic Zoology, Institute of Zoology,

Jagiellonian University,

R. Ingardena 6 ,

30-060 Kraków, Poland

e-mail: monika.zelazowska@uj.edu.pl

W. Kilarski

Department of Cytology and Histology, Institute of Zoology,

Jagiellonian University,

Kraków, Poland 